\title{
An Overview of Plant Photosynthesis Modulation by Pathogen Attacks
}

\author{
Kumarakurubaran Selvaraj ${ }^{1,2}$ and Bourlaye Fofana ${ }^{1}$ \\ ${ }^{1}$ Crops and Livestock Research Centre, Agriculture and Agri-Food Canada, \\ Charlottetown, PE, \\ ${ }^{2}$ Department of Biology, University of Prince Edward Island, Charlottetown, PE,
}

Canada

\section{Introduction}

In 1893, Charles Barnes (1858-1910) proposed to designate the biological process for "synthesis of complex carbon compounds out of carbonic acid, in the presence of chlorophyll, under the influence of light" as "photosyntax" or "photosynthesis". His preference went for the word "photosyntax", but "photosynthesis" came into common usage as the term of choice (Gest, 2002). Although this definition is still widely used today, the Oxford English Dictionary (OED, 1989) has defined the biological photosynthesis as "the process by which carbon dioxide is converted into organic matter in the presence of the chlorophyll of plants under the influence of light, which in all plants except some bacteria involves the production of oxygen from water". By considering the photosynthetic bacteria that do not produce oxygen and do not necessarily require carbonic acid as carbon source, Gest (Gest, 1993) has refined these definitions as followed: "photosynthesis is a series of processes in which electromagnetic energy is converted to chemical energy used for biosynthesis of organic cell materials; a photosynthetic organism is one in which a major fraction of the energy required for cellular syntheses is supplied by light". Photosynthesis is therefore a unique source for carbon sequestration and allows the aerobic organisms to survive based upon not only on its released oxygen but also its synthesized organic compounds. As such, plants are an ideal host for pathogenic microorganisms such as fungi, bacteria and viruses and also the only food source for herbivores. Theoretically, the photosynthetic capacity of plants is unlimited when the optimal growing conditions are met. Unfortunately, terrestrial plants are constantly challenged by abiotic (UV, water, salinity, temperature) (Baker et al., 1988, Baldry et al., 1966, Barhoumi et al., 2007, Barrow and Cockburn, 1982, Bassham, 1977, Batista-Santos et al., 2011, Bauerle et al., 2007, Berry, 1975, Bischof et al., 2000, Ripley et al., 2008, Ripley et al., 2007, Roberntz and Stockfors, 1998) and biotic (pathogens, pests, animal and human) stresses that reduce their productivity and even threaten their survival (Bilgin et al., 2010, Bonfig et al., 2006, Erickson and Hawkins, 1980, Garavaglia et al., 2010, Kocal et al., 2008, Tang et al., 2009). While the regulation of plant defence responses has been extensively investigated, the effects of pathogen infection on primary metabolism, including photosynthesis, are however less known. Currently, interest in this research area is growing and some aspects of photosynthesis, assimilate 
partitioning, and source-sink regulation in different types of plant-pathogen interactions have been investigated. Berger et al (Berger et al., 2007) have recently reviewed how plant physiology meets phytopathology. The reader can also get more detail on this topic in previous study (Trotta et al., 2011, Essmann et al., 2008, Scharte et al., 2009). Here, we will focus our review on current knowledge on the process of higher plant photosynthesis, its outcome for both plants and fungal pathogens, the roles for some of the metabolites and transduction pathways that are implicated in this twined inter-relationship as well as the potential targets as future strategy.

\section{Photosynthesis and pathogen}

Plants and pathogens have developed dynamic interactions. Whereas plants tend to survive through different mechanisms following pathogen attack, the later looks for maximizing feed intake to insure its reproduction and dissemination (Korves and Bergelson, 2003, Berger et al., 2007). In this context, the photosynthetate - the energy source for both the plant and pathogens - synthesis and its availability is the focus of a struggle to death. The next section will discuss how photosynthesis proceeds in these challenging conditions.

\subsection{Photosynthesis}

Chloroplast is the factory for photosynthesis in higher plants. However, new evidences suggest a contribution for mitochondrial functions in the maintenance of efficient photosynthesis (Nunes-Nesi et al., 2008). The general process of photosynthesis, its outcome and limiting factors will be briefly described in the next sections.

\subsubsection{Process and outcome}

\subsubsection{Process}

In higher plants, the photosynthetic $\mathrm{CO}_{2}$ fixation occurs in the green leaves, considered as source organs, with the absorption of light by chlorophyll, much of which is located in the light-harvesting complexes (LHCs) of PSII and PSI within the thylakoid membrane of chloroplasts (Murchie and Niyogi, 2011). The mesophyll cell of higher plants, due to its higher chloroplast content, is the most active photosynthetic tissue. In general photosynthesis proceeds through 2 major phases: a) a light phase that produces ATP and $\mathrm{NADPH}$ in the chloroplast thylakoids and released in the stroma and b) the $\mathrm{CO}_{2}$ reduction phase in presence of water in the stroma and that consumes the ATP and NADPH generated in phase a) to produce a triose phosphate through the Calvin-Benson cycle which comprises three stages (Figure 1).

Briefly, the carboxylation of 3 molecules of ribulose 1,5 biphosphate fixes 3 molecules of $\mathrm{CO}_{2}$ and $\mathrm{H}_{2} \mathrm{O}$ under the ribulose 1,5 biphosphate carboxylase/oxygenase (rubisco) catalysis in the Calvin-Benson cycle and leads to 6 molecules of 3-phosphoglycerate. The 3phosphoglycerates are then phosphorylated in presence of ATP produced during the light reaction by the catalytic action of 3-phosphoglycerate kinase into 1,3 bisphosphoglycerate which is further reduced by NADPH and NADP-glyceraldehyde 3-phosphate dehydrogenase into 6 molecules of glyceraldehyde 3-phosphate (6 triose phosphates). Of these six triose phosphates, one represents the net synthesis from $\mathrm{CO}_{2}$ fixation and, 9 ATP and $6 \mathrm{NADPH}$ are utilized. The remaining five triose phosphates are used to regenerate the ribulose 1,5 biphosphate to insure continuous $\mathrm{CO}_{2}$ fixation (Taiz and Zeiger, 2010). 


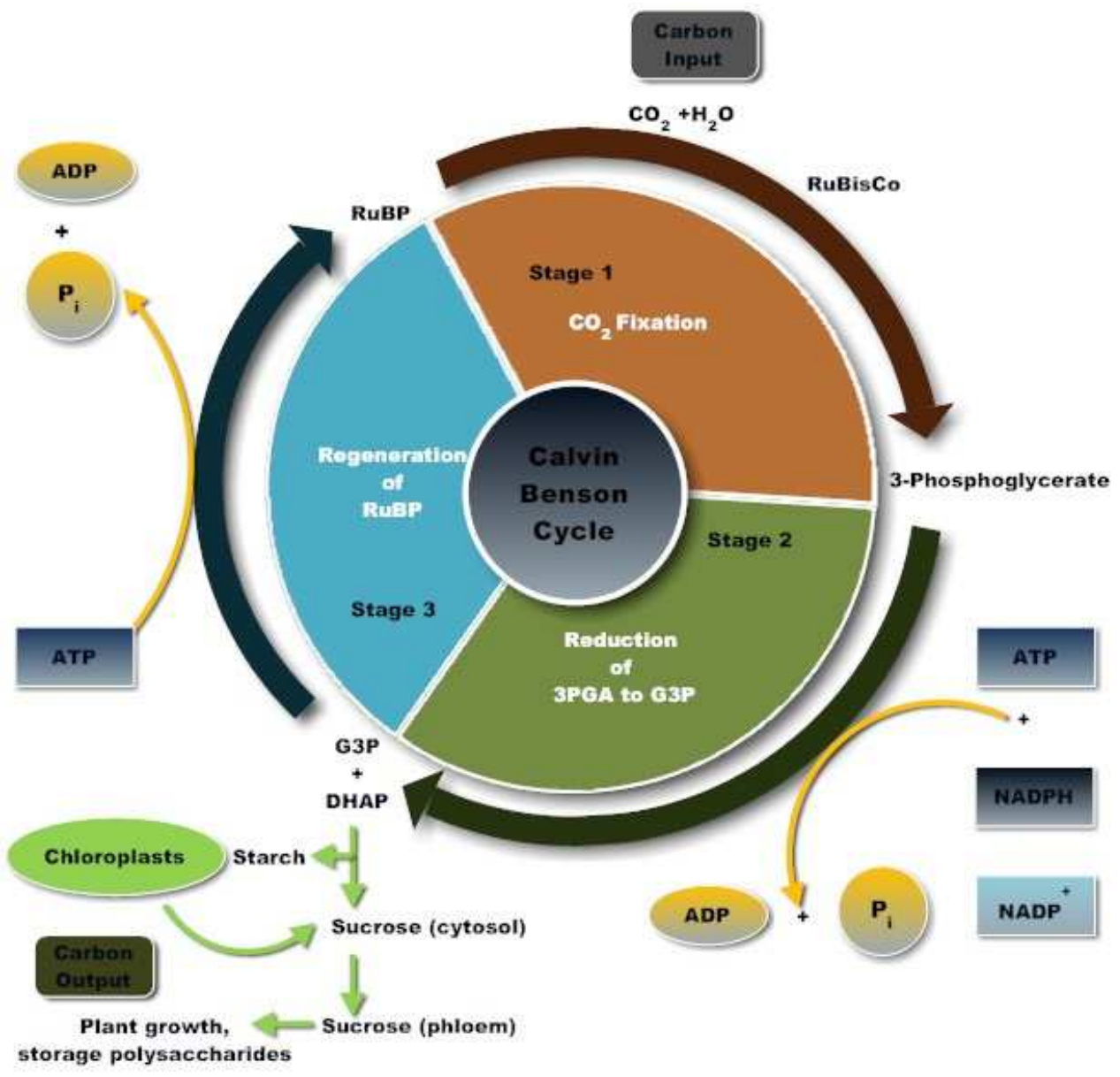

Fig. 1. Calvin-Benson cycle adapted from Taiz and Zeiger (Taiz and Zeiger, 2010)

\subsubsection{Outcome}

The outcome of $\mathrm{CO}_{2}$ fixation by higher photosynthetic plants is the production of carbohydrates. As a result of photosynthetic $\mathrm{CO}_{2}$ reduction during the day, starch granules accumulate in the chloroplast while an excess of assimilates are continuously allocated, mostly in the form of sucrose, to sink tissues such as developing leaves, roots, meristems, fruits, and flowers, that are unable to produce sufficient amounts of assimilates by themselves and therefore require their net import via the phloem (Kocal et al., 2008). Sucrose is loaded into the phloem in the minor veins of leaves before export (Zhang and Turgeon, 2009). Recently, Zhang and Turgeon (Zhang and Turgeon, 2009) have proposed two active, species-specific loading mechanisms. One involves transporter-mediated sucrose transfer from the apoplast into the sieve element-companion cell complex, so-called apoplastic loading. In the second putative mechanism, sucrose follows an entirely symplastic pathway, and the solute concentration is elevated by the synthesis of raffinose and stachyose in the 
phloem, not by transporter activity. Thus, a coordinated sequence of assimilate production, allocation, and utilization is essential for normal plant growth and development (Kocal et al., 2008). Indeed, carbohydrate accumulation in the leaves can lead to decreased expression of photosynthetic genes and accelerated leaf senescence when there is an imbalance between source and sink at the whole plant level (Paul and Foyer, 2001). Generally, when sink activity is decreased by removing active sinks or introducing nutrient deficiency, carbohydrates accumulate in leaves and photosynthesis becomes inhibited (Ainsworth and Bush, 2011, Paul and Pellny, 2003). Similarly, when sucrose export from source leaves is restricted, for example by cold girdling of petioles or down-regulation of sucrose transporter abundance, photosynthesis is inhibited. It has also been reported that a downregulation of sucrose transporter 1 (SUT1) in several sucrose-transporting plants, shown to be apoplastic loaders, led to an accumulation of sugars and leaf chlorosis (Zhang and Turgeon, 2009). In contrast, no such phenotype developed when a symplastic loading plant such as Verbascum phoeniceum was downregulated, emphasizing the importance of either active or passive assimilates exports.

\subsubsection{Limiting factors}

Although the Calvin-Benson cycling capacity seems unlimited in the presence of light, $\mathrm{CO}_{2}$ and $\mathrm{H}_{2} \mathrm{O}$, many limiting factors counteract this highly regulated biological process. First, if the presence of $\mathrm{CO}_{2}$ and light are required, their levels are of great importance. As light (photon flux and intensity) increases (in constant optimal $\mathrm{CO}_{2}$ ), the rate of photosynthesis rises until it is saturated. An excess of light can lead to photoinhibition (Bertamini and Nedunchezhian, 2004, Murchie and Niyogi, 2011). A correlation between the in vivo rates of net $\mathrm{CO}_{2}$ assimilation and the atmospheric $\mathrm{CO}_{2}$ concentrations was observed when intact $\mathrm{C}_{3}$ and $\mathrm{C}_{4}$ plants were exposed to different atmospheric $\mathrm{CO}_{2}$ concentrations (Aguera et al., 2006, Ainsworth and Rogers, 2007, Bhatt et al., 2010). In general, current atmospheric $\mathrm{CO}_{2}$ concentration is adequate for both $\mathrm{C}_{3}$ and $\mathrm{C}_{4}$ plants. However, with global warming and its related rising temperature and $\mathrm{CO}_{2}$ level, a higher biomass production and a change in $\mathrm{C}_{3}$ and $\mathrm{C}_{4}$ plants distribution are expected (depending on rainfall) because of their differential photosynthetic and water use efficiency. Nontheless, many temperate plant species may not adapt as rate of photosynthesis was found to decline at moderately high temperature in a temperate species such as Arabidopsis thaliana (Kumar et al., 2009, Kurek et al., 2007). If $\mathrm{CO}_{2}$ generally favours photosynthesis, other environmental clues such as UV-B (Albert et al., 2008), heat shock and water deficit (Abrams et al., 1990, Ackerson and Hebert, 1981, Allakhverdiev et al., 2008, ZhangWollenweber et al., 2008), Cold (Batista-Santos et al., 2011, Bilska and Sowinski, 2010), herbivore and pathogen attacks have detrimental effects on photosynthesis (Halitschke et al., 2011, Horst et al., 2008, King and Caylor, 2010, Nabity et al., 2009). The primary targets of thermal damage in plants are the oxygen evolving complex along with the associated cofactors in photosystem II (PSII), carbon fixation by Rubisco and the ATP generating system (Allakhverdiev et al., 2008). Recent studies on the combined effect of moderate light intensity and heat stress suggest that moderately high temperatures do not cause serious PSII damage but inhibit the repair of PSII. Repair of PSII involves de novo synthesis of proteins, particularly the D1 protein of the photosynthetic machinery that is damaged due to generation of reactive oxygen species (ROS). Attacks by ROS during moderate heat stress principally affects the repair system of PSII, resulting in the reduction of carbon fixation and oxygen evolution, as well as the disruption of the linear electron flow (Allakhverdiev et al., 2008). 


\subsection{Pathogens in plants}

Plants pathogens are of diverse nature and include pathogenic fungi, virus, and bacteria. Whereas all of these pathogens are of great interests for plant biologists, the sake of this contribution will be limited to the pathogenic fungi with some reference to bacteria.

\subsubsection{Invasion process}

Plant infection by pathogenic fungi and bacteria can occur in multiple ways. It could be passive, i.e. accidental, by suction into the plant through natural plant openings such as stomata, hydathodes or lenticels, entrance through abrasions or wounds on leaves, stems or roots (Hu and Rijkenberg, 1998b, Vidaver and Lambrecht, 2004). Infection of host plants by biotrophic plant pathogens generally involves the sequential development of specialized host-parasite interfaces, exemplified by those of haustoria, which are maintained over an extended period of time without causing significant cytological damage to host tissue in the infected region (Tariq and Jeffries, 1984, Tariq and Jeffries, 1986). Using scanning electron microscopy, $\mathrm{Hu}$ and Rijkenberg (Hu and Rijkenberg, 1998b) identified key time points in the formation of infection structures by $P$. triticinia on susceptible and resistant lines of hexaploid wheat. Six hours after infection, the fungus forms appressoria over stomata openings. After 12 hours, the fungus has successfully penetrated into the stroma, formed substomatal vesicles (SSV), and primary infection hyphae are visible. After SSV formation, the primary infection hypha grows and attaches to a mesophyll or epidermal cell. At 24 hours postinoculation, a septum appears separating the haustorial mother cell from the infection hypha after which the fungus forms haustorium and penetrates the cell ( $\mathrm{Hu}$ and Rijkenberg, 1998b). Recently, Garg et al (Garg et al., 2010) described the infection process in susceptible and resistant genotypes of Brassica napus against Sclerotinia sclerotiorum. They demonstrated at the cellular level that resistance to S. sclerotiorum in B. napus is a result of retardation of pathogen development, both on the plant surface and within host tissues. There are some indications that the infection process is dependent on the nutritional status of the inoculums (Garg et al., 2010). Indeed, previous studies suggested that the presence of nutrients is essential for hyphal development, penetration and for subsequent establishment of a successful invasion of a susceptible host by the pathogen (Tariq and Jeffries, 1984, Tariq and Jeffries, 1986, Garg et al., 2010).

\subsubsection{Outcomes of pathogen invasion}

\subsection{For the pathogen}

Plant pathogens like viruses, fungi, oomycetes, and bacteria are known to interfere with the source-sink balance (Berger et al., 2007, Biemelt and Sonnewald, 2006, Seo et al., 2007), and in the case of a successful interaction, pathogens are believed to reprogram a plant's metabolism to their own benefit (Biemelt and Sonnewald, 2006). This comprises the suppression of plant defence responses and the reallocation of photoassimilates to sufficiently supply the pathogen with nutrients (Kocal et al., 2008). In accordance with this, the infected leaf is assumed to undergo a source to sink transition or retains its sink character. For example, infection of maize leaves with Ustilago maydis prevents establishment of $\mathrm{C}_{4}$ photosynthesis because $U$. maydis-induced leaf galls exhibited carbon dioxide response curves, $\mathrm{CO}_{2}$ compensation points and enzymatic activities that are characteristic of $C_{3}$ photosynthesis (Horst et al., 2008). An indication for this is provided by a stimulation of cell wall-bound invertase (cw-Inv) that mobilizes hexoses at the infection site and a decreased rate of photosynthesis (Kocal et al., 2008). 


\subsection{For the plant}

Pathogen attacks result in the development of symptoms that include leaf and fruit wilt, stem and root rot (Rekah et al., 1999), coverage of leaf surface with pustule, chlorosis and necrosis (Fofana et al., 2007, Kocal et al., 2008) (Figure 2), a decreased rate of plant photosynthesis (Kocal et al., 2008), and as a consequence plant death or yield loss ensues (Berger et al., 2007).

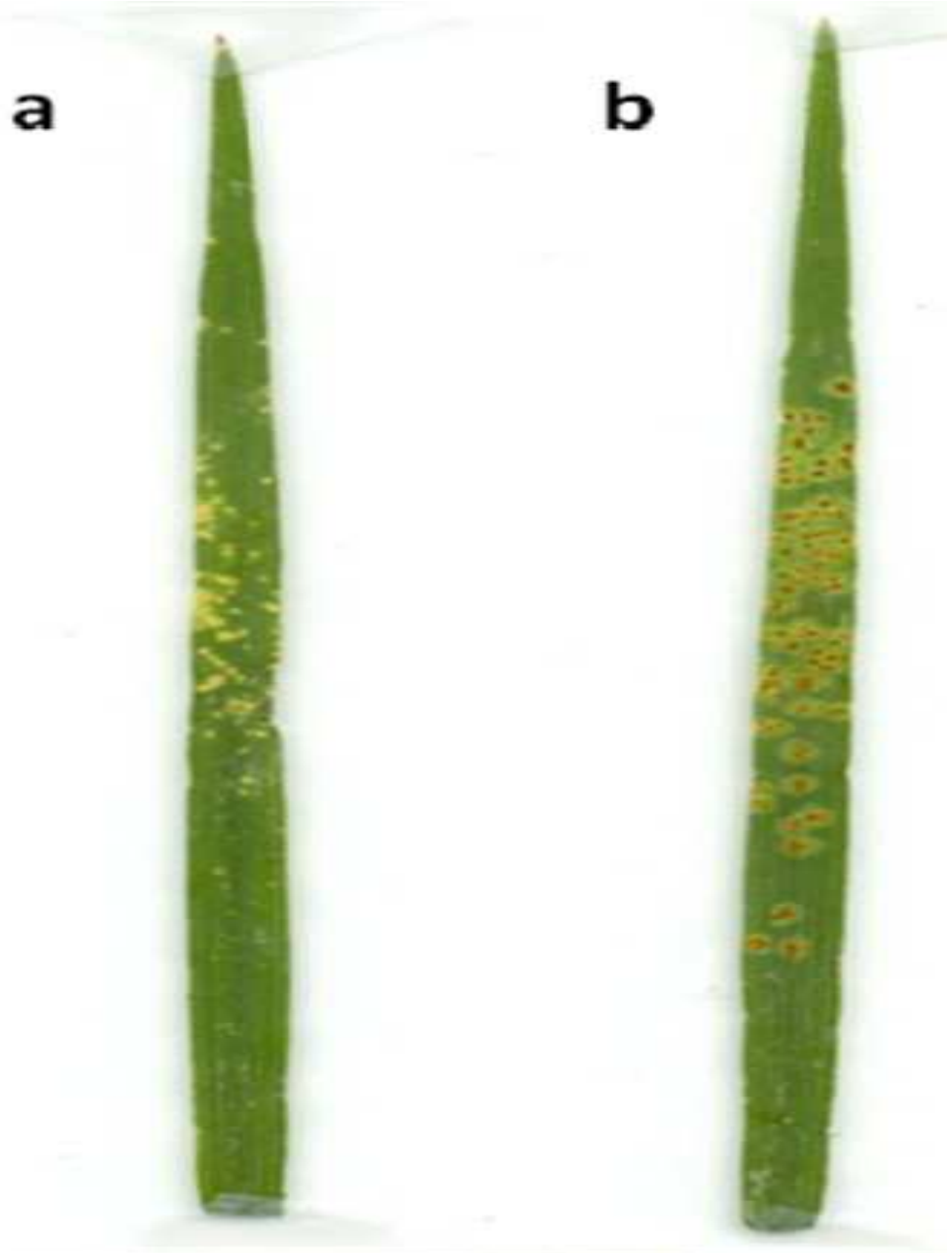

Fig. 2. Symptoms of wheat leaf rust (Pucinia triticina) on wheat near isogenic RL6003 line inoculated with a) avirulent race 1 (BBB), and b) virulent race 7-2 (TJB) of Pucinia triticina. An incompatible interaction showing ; 1 - infection types with very small pustules, no sporulation and hypersensitive reaction (BBB) and compatible interaction showing a 3+4infection type with large pustules, abundant sporulation and chlorotic reaction around sporulations (TJB). 


\subsection{Photosynthesis and pathogens invasions}

\subsubsection{Photosynthesis efficiency under pathogen attacks}

Pathogen attacks result in a decreased rate of plant photosynthesis (Kocal et al., 2008), and as a consequence yield loss (Berger et al., 2007). Pathogen infection often leads to plant death, the development of chlorotic and necrotic (Kim et al., 2010) lesions and to a decrease in photosynthetic assimilate production. Using chlorophyll fluorescence imaging, it has been reported that the changes in photosynthesis upon infection are local. In Arabidopsis leaves infected with $A$. candida and in tomato plants infected with $B$. cinerea, a ring of enhanced photosynthesis was detectable surrounding the area with decreased photosynthesis at the infection site. At present, it is not clear if this stimulation of photosynthesis is due to the defence strategy of the plant (Berger et al., 2007). A decrease in photosynthesis has also been reported in incompatible interactions (Bonfig et al., 2006). The decrease in photosynthesis was detectable earlier with the avirulent strain than with the virulent strain. It is suggested that plants switch off photosynthesis and other assimilatory metabolism to initiate respiration and other processes required for defence (Berger et al., 2007). Recently, Petit et al (Petit et al., 2006) characterized the photosynthetic apparatus of grape leaves infected with esca disease. Foliar symptoms were associated with stomatal closure and alteration of the photosynthetic apparatus. A decrease in $\mathrm{CO}_{2}$ assimilation, transpiration, a significant increase in intercellular $\mathrm{CO}_{2}$ concentration, a strong drop in the maximum fluorescence yield and the effective Photosystem II quantum yields, and a reduction of total chlorophyll but a stable carotenoid content were reported (Petit et al., 2006).

\subsubsection{Mechanistic alteration of the photosynthetic capacity}

Several mechanisms have been described to explain the suppression of plant defence responses and the reprogramming of the plant's metabolism to the pathogen own benefit (Garavaglia et al., 2010). The pathogens Stagonospora nodorum and Pyrenophora tritici-repentis, the causal agents of Stagonospora nodorum blotch (SNB) and tan spot, respectively, produce multiple effectors (Ptr ToxA, Ptr ToxB, and Ptr ToxC), also known as host-selective toxins (HSTs), that interact with corresponding host sensitivity genes in an inverse gene-for-gene manner to cause the diseases in wheat. A compatible interaction requires both the effector (HST) and the host gene and results in susceptibility as opposed to host resistance (R) genes. R-genes lead to a resistance response known as effector-triggered immunity (ETI) which includes localized programmed cell death (PCD) or hypersensitive response (HR), to restrict pathogen growth. The absence of either the effector or the host gene results in an incompatible interaction (Zhang et al., 2011, Faris et al., 2010). Pyrenophora tritici-repentis produces oval or diamond-shaped to elongated irregular spots that enlarge and turn tan with a yellow border and a small dark brown spot near the center causing necrotic and/or chlorotic lesions on infected leaves, which can significantly reduce total photosynthetic area and yield loss (Kim et al., 2010). The development of chlorosis in response to Ptr ToxB results from an inhibition of photosynthesis in the host, leading to the photooxidation of chlorophyll molecules as illuminated thylakoid membranes become unable to dissipate excess excitation energy (Strelkov et al., 1998). Recently, Kim et al (Kim et al., 2010) showed that treatment of wheat leaves with Ptr ToxB results in significant changes in the abundance of more than 100 proteins, including proteins involved in the light reactions of photosynthesis, the Calvin cycle, and the stress/defence response. These authors also examined the direct effect of Ptr ToxB on photosynthesis and found a net decline of photosynthesis within $12 \mathrm{~h}$ of toxin-treatment, long before chlorosis develops at $48-72 \mathrm{~h}$. A 
role for ROS generation and disruptions of the photosynthetic electron transport shortly after pathogen attack or toxin treatment have been suggested as potential mechanism (Kim et al., 2010). Similar mechanism has been proposed by Allakhverdiev et al (Allakhverdiev et al., 2008) following heat stress that targets the oxygen evolving complex along with the associated cofactors in photosystem II (PSII), carbon fixation by rubisco and the ATP generating system. In another system, Kocal et al (Kocal et al., 2008) studied the role of cell wall invertase (cw-Inv) in transgenic tomato (Solanum lycopersicum) plants silenced for the major leaf $\mathrm{cw}$-Inv isoforms during normal growth and during the compatible interaction with Xanthomonas campestris pv vesicatoria. $\mathrm{Cw}$-Inv expression was found to be induced upon microbial infection and was most likely associated with an apoplastic hexose accumulation during the infection process. The hexoses formed are thought to aid the pathogen's nutrition (Berger et al., 2007, Biemelt and Sonnewald, 2006, Seo et al., 2007). Fungal pathogens also produce their own invertases to ensure their nutritional supply (Chou et al., 2000, Voegele et al., 2006). One of the most sophisticated mechanisms that divert plant metabolites to pathogen is the role of auxin in host-pathogen interactions (Fu et al., 2011, Navarro et al., 2006). Indole-3-acetic acid (IAA) is the major form of auxin in most plants and induces the loosening of plant cell wall, the natural protective barrier to invaders. X. oryzae pv oryzae, $X$. oryzae pv oryzicola, and $M$. grisea secrete IAA, which, in turn, may induce rice to synthesize its own IAA at the infection site. IAA induces the production of expansins, the cell wallloosening proteins, and makes rice vulnerable to pathogens (Fu et al., 2011). Similarly, Garavaglia et al (Garavaglia et al., 2010) have reported an eukaryotic-acquired gene by a biotrophic phytopathogen that allows its prolonged survival on the host by counteracting the shut-down of plant photosynthesis.

\section{Plant reactions to pathogen attack}

During plant-pathogen interactions, the host develops a variety of defence reactions. Nonhost resistance against a biotrophic fungal pathogen is often manifested as the ability of the attacked plant to prevent fungal penetration, or the ability to terminate the development and/or functioning of the fungal feeding structure such as the intracellular hypha or the haustorium before it extracts enough nutrition from the plant cells (Wen et al., 2011). These reactions may involved development of physical barriers such as exocytosis, cell wall modifications and de novo metabolites synthesis (IshiharaHashimotoMiyagawa et al., 2008).

\subsection{Primary metabolites and secondary metabolite production}

\subsubsection{Primary metabolites}

Cell wall strengthening by callosic (Wen et al., 2011) and papillae formation, cell wall apposition (Fofana et al., 2005, Wurms et al., 1999), lignin deposition (Hammerschmidt and Kuc, 1982) as well as hydrolytic PR proteins (Hu and Rijkenberg, 1998a) have been reported as first line of defence mechanism developed by plants. Components of these cell wall makeups are of primary metabolite origin. It is worth noting that papillae were at times observed as an initial response to fungal penetration. Generally, papillae relate to powdery mildew fungal penetration in two ways: in some instances, penetration fails when papillae are present and alternatively, penetration may succeed and the papilla becomes a collar for the haustorial neck (Hammerschmidt and Yang-Cashman, 1995). Using transmission electron microscopy, Fofana et al (Fofana et al., 2005) observed both outcomes for elicited and nonelicited cucumber plants, strongly suggesting that papillae formation alone may not be sufficient to explain the level of 
induced resistance observed for elicited plants. Moreover, chitin labelling revealed that the walls and lobes of fungal haustoria within both treatments were undisturbed, suggesting that PR proteins, such as chitinases and $\beta$-1,3-glucanases, may not play a major role in the early events of induced resistance for cucumber (Fofana et al., 2005). However, Gonzalez-Teuber et al. (Gonzalez-Teuber et al., 2010) recently reported glucanases and chitinases as causal agents in the protection of acacia extrafloral nectar from infestation by phytopathogens. Nectars are rich in primary metabolites and as protective strategy, floral nectar of ornamental tobacco (Nicotiana langsdorffii $x$ Nicotiana sanderae) contains "nectarins," proteins producing reactive oxygen species such as hydrogen peroxide. By contrast, Acacia extrafloral nectar contains pathogenesis-related (PR) proteins. This nectar is secreted in the context of defensive reactions. Gonzalez-Teuber et al (Gonzalez-Teuber et al., 2010) showed that PR proteins causally underlie the protection of Acacia extrafloral nectar from microorganisms and that acidic and basic glucanases likely represent the most important prerequisite in this defensive function. Salicylic acid (SA) and Jasmonic acid have long been considered as signal molecules in disease resistance (Ward et al., 1991). Recently, Arabidopsis GH3-type proteins functioning in auxin signaling, in association with a salicylic acid (SA)-dependent pathway, was reported to positively regulate resistance to Pseudomonas syringae (Jagadeeswaran et al., 2007). Accordingly, Fu et al (Fu et al., 2011) suggested that GH3-2 encodes an IAA-amido synthetase and positively regulates rice disease resistance by suppressing pathogen-induced accumulation of IAA in rice. Activation of GH3-2 confers to rice a broad spectrum and partial resistance against Xanthomonas oryzae pv oryzae and Xanthomonas oryzae pv oryzicola and the fungal Magnaporthe grisea in rice.

\subsubsection{Secondary metabolites}

The role for secondary metabolites in the plant's interaction with its environment is widely recognized (Rhodes, 1994). The primary metabolites deriving from photosynthesis are channeled into different metabolite pathways for the synthesis, storage, and modification (hydroxylation, glycosylation, acetylation, etc) of myriads of compounds, and for use to cope abiotic and biotic clues. Within each of the major groups of secondary metabolites such as alkaloids, phenylpropanoids and terpenoids, several thousand individual compounds accumulating in plants have been characterised and their role in plant-pathogen interactions studied (Ishihara et al., 2011). For example, induction of phenolic compounds, flavonoid phytoalexins, (Daayf et al., 1997, Fawe et al., 1998, Fofana et al., 2002, McNally et al., 2003b, McNally et al., 2003) was reported in cucumber plants following pathogen attacks and elicitor treatments. Synthesis of phytoalexins involves the rapid transcriptional activation of genes encoding a number of key biosynthetic enzymes that include anthranilate synthase (AS) (IshiharaHashimotoTanaka et al., 2008) phenylalanine ammonia-lyase (PAL), chalcone synthase (CHS) which is the early committed key enzyme of the flavonoid/isoflavonoid pathway, chalcone isomerase (CHI) and isoflavone reductase (IFR) (Dixon et al., 1995, Baldridge et al., 1998, Fofana et al., 2002, Fofana et al., 2005). The chemical nature of some of these compounds is now well elucidated (Ibanez et al., 2010, Ishihara et al., 2011, McNally et al., 2003). McNally et al (McNally et al., 2003b, McNally et al., 2003) reported the synthesis of complex C-glycosyl flavonoid phytoalexins, referred to as vitexin-6-(4-hydroxy-1ethylbenzene) (cucumerin A) and isovitexin-8-(4-hydroxy-1-ethylbenzene) (cucumerin B), as a site-specific response to fungal penetration in cucumber. In a recent study, Ishihara et al (IshiharaHashimotoTanaka et al., 2008) reported on an induced accumulation of Trp- 
derived secondary metabolites, including tryptamine, serotonin, and hydroxycinnamic acid amides of serotonin in rice leaves by infection with Bipolaris oryzae. Using enantiomers of a(fluoromethyl)tryptophan (aFMT - R- and S- aFMT), S-aFMT but not R-aFMT effectively inhibited tryptophan decarboxylase activity extracted from rice leaves infected by Bipolaris oryzae, suppressed accumulation of serotonin, tryptamine, and hydroxycinnamic acid amides of serotonin in a dose-dependent manner, and lead to were severely damaged leaves showing lesions that lacked deposition of brown materials, compared to control without SaFMT. Administration of tryptamine to S-aFMT-treated leaves restored accumulation of tryptophan-derived secondary metabolites as well as deposition of brown material and reduced damage caused by fungal infection (Ishihara et al., 2011).

\subsection{Transduction pathways}

Plants have developed a sophisticated innate immune surveillance system to recognize pathogens (Dodds and Rathjen, 2010, Liu et al., 2011). This surveillance system consists of an integral plasma membrane proteins with extracellular receptor domains to perceive conserved pathogen associated molecular patterns (PAMPs) presented by pathogens during infection, and an intra- cellular Resistance (R) proteins to recognize the presence of specific pathogen effector proteins in host cells (Elmore et al., 2011). Two recognition models have been reported for non-host resistance (non-race specific elicitor as signal) and gene-for-gene resistance (race-specific elicitor/ avirulence gene products as signal) interactions, with a receptor and a resistance gene product as signal perception, respectively (Romeis, 2001). Upon perception, takes place a signal transduction cascade involving protein kinases and cellular responses to the intruders ensue. Either the disease develops or resistance phenotypes are observed. For review, please see more details in previous reports (Romeis et al., 2001, Romeis, 2001, Elmore et al., 2011, Elmore and Coaker, 2011a, Liu et al., 2011, Elmore and Coaker, 2011b). The plant reaction to the outcome of signalling has a dramatic consequence on the plant's ability to photosynthesize even in incompatible interactions where HR responses lead to a localized cell death at infection sites and restrict the pathogen progression. In these conditions, with patchy leaf area (no chlorophyll for light inception), the photosynthetic capacity is reduced compared to non-infected plants.

\section{New insights from the genomics and proteomics era}

The genomics and proteomics era, with its high-throughput capability, has enabled the expression profiling analysis of thousands of genes and proteins simultaneously (Lee et al., 2004). Hence, the global analysis of many plant processes, including the response to pathogen attack, their interlinked regulatory networks and signalling pathways have been made possible (Duggan et al., 1999, Eulgem, 2005, GuldenerSeong et al., 2006, Schenk et al., 2000).

\subsection{Gene and protein networks in plant-pathogen interactions \\ 4.1.1 In the pathogen}

One of the challenges faced by biologists in plant-pathogen interactions was their ability to differentiate plant genes from the pathogen genes. This has become feasible with the release of the genome sequences for several fungus and plant species. Exploiting these genomic resources it has been possible to design and perform the wide-genome microarray transcription profiling of the plant pathogenic fungus, Fusarium graminearum, grown in 
culture media under different nutritional regimes and in comparison with fungal growth in infected barley (GuldenerSeong et al., 2006). Guldener et al. (GuldenerSeong et al., 2006) were able to detect the fungal gene expression during plant infection, test for sensitivity limits for detecting fungal RNA in planta and the potential for cross-hybridization between fungal probe sets and plant RNAs. A total of 11,994 of a possible 17,809 Fusarium probe sets $(67.35 \%)$ were detected under various conditions of the fungus grown in culture and a total of 7132 probe sets $(40.05 \%)$ were detected from the fungus during infection of barley. As of July 5, 2011 however, only 96 pathogenic genes from F. graminearum curated for lab experimental, molecular and biological information on genes proven to affect the outcome pathogen-host interactions in cereals (oat, wheat, barley, rye, maize), Arabidopsis, and tomato were reported in PHI-base database (http://www.phi-base.org/query.php) and 4000 proteins that have been annotated in MIPS F.graminearum Genome Database (FGDB), (GuldenerMannhaupt et al., 2006) which is far from complete. To speed up the process, a computational network approach to predict pathogenic genes for Fusarium graminearum was proposed by Liu et al (Liu et al., 2010). With a small number of known pathogenic genes as seed genes, the authors were able to identify a subnetwork that consists of potential pathogenic genes from the protein-protein interaction network (PPIN) of F. graminearum, where the genes in the subnetwork generally share similar functions and are involved in similar biological processes. The genes that interact with at least two seed genes can be identified because these genes are more likely to be pathogenic genes due to their tight interactions with the seed genes. The protein-protein interactions that connect networks with each other are thought to be the signalling pathways between biological processes. On the basis of our current understanding of pathogenicity of model pathogens, F. graminearum is thought to organize a complex network of proteins and other molecules, including those that might be secreted into host cells, to adapt the life inside its host plant. Hence, Zhao et al (Zhao et al., 2009) showed that F. graminearum protein-protein interactions (FPPI) contains 223,166 interactions among 7406 proteins which represent about $52 \%$ of the whole $F$. graminearum proteome. Although these computational predictions are fascinating, system biology based on experiment data is also making considerable progress. Song et al (Song et al., 2011) reported the first proteome of infection structures from parasitized wheat leaves, enriched for Puccinia triticina (Pt) haustoria using 2-D PAGE MS/MS and gel-based LC-MS (GeLC-MS) to separate proteins. They compared the generated spectra with a partial proteome predicted from a preliminary Pt genome and ESTs, with a comprehensive genome-predicted protein complement from the related wheat stem rust fungus, Puccinia graminis f. sp. tritici $(P g t)$, and with various plant resources. The authors identified over 260 fungal proteins, 16 of which matched peptides from Pgt. Based on bioinformatic analyses and/or the presence of a signal peptide, at least 50 proteins were predicted to be secreted. Among those, six had effector protein signatures, some were related and the respective genes of several seem to belong to clusters. Many ribosomal structural proteins, proteins involved in energy, general metabolism and transport were detected. By measuring the gene expression over several life cycle stages of ten representative candidates using quantitative RT-PCR, all tested genes were shown to be strongly upregulated and of which four were expressed solely upon infection (Song et al., 2011). Similarly, El-Bebany et al (El-Bebany et al., 2010) identified potential pathogenicity factors including isochorismate hydrolase, a potential plant-defence suppressor that may inhibit the production of salicylic acid, which is 
important for plant defence response signaling. Much progress is still needed not only in the identification but in the mechanistic action of the genes and proteins identified.

\subsubsection{In the plant}

The role of photosynthesis in plant defence is a fundamental question awaiting further molecular and physiological elucidation. Different pathogens, based on life cycle (biotroph vs necrotroph), develop different pathogenesis mechanisms that impact differently on the plant's photosynthesis efficiency as well as on its gene and proteome profiling. Xanthomonas axonopodis $p v$. citri, the bacterial pathogen responsible for citrus canker encodes a plant-like natriuretic peptide (XacPNP) that is expressed specifically during the infection process and prevents deterioration of the physiological condition of the infected tissue to the benefit of the invaders (Nembaware et al., 2004, Gehring and Irving, 2003). The wild pathogen expressing the XacPNP peptide maintains the plant in a condition that prevents chlorosis and no significant drop of photosynthesis. In contrast, citrus leaves infected with a XacPNP deletion mutant (DeltaXacPNP) resulted significant reduction of photosynthesis efficiency, and proteomic assays revealed a major reduction in photosynthetic proteins such as Rubisco, Rubisco activase and ATP synthase as a compared with infection with wild type bacteria (Garavaglia et al., 2010). Similarly, Pyrenophora tritici-repentis, is an important foliar disease of wheat. The fungus produces the host-specific, chlorosis-inducing toxin Ptr ToxB. Kim et al (Kim et al., 2010) examined the effects of Ptr ToxB on sensitive wheat. Photosynthesis was significantly reduced within $12 \mathrm{~h}$ of toxin treatment, prior to the development of chlorosis at 48-72 h. Proteomics analysis by 2-DE revealed a total of 102 protein spots with significantly altered intensities 12-36 h after toxin treatment, of which 66 were more abundant and 36 were less abundant than in the buffer-treated control. In the last decade, an abundant literature has treated large dataset gene expression profiling of plant-pathogen interactions (Bilgin et al., 2010, Eichmann et al., 2006, Fofana et al., 2007, Lee et al., 2004, Zou et al., 2005) among many others. Of interest was the study by Fofana et al (Fofana et al., 2007) where difference in temporal gene expression profiling of the wheat leaf rust pathosystem was reported in compatible and incompatible defence pathways using cDNA microarray. Gene ontology assignment of differentially expressed genes showed alterations in gene expression for different molecular functions, cellular location and biological process for genes (Figure 3). The authors observed changes in the expression of genes involved in different biological processes such as photosynthesis, redox control, resistance and resistance-related genes (NBS-LRR, cyclophilin-like protein, MLo4-like gene, MRP1), components of the shikimatephenylpropanoid pathway as well as genes involved in signal transduction (Myb-like transcription factors, calmodulin MAPKK, PI4PK), heat shock proteins, osmotic control genes and metabolisms (Fofana et al., 2007). Six hours after inoculation, a coordinated decrease in transcription of photosynthesis genes (photosystemmII phosphoprotein, ribulose-1,5 biphosphate carboxylase/oxygenase small unit, Type III LHCII CAB precursor protein, photosystem II type II chlorophyll A/B-binding protein, ribulose-1,5 biphosphate carboxylase activase) in the resistant but not susceptible interactions was observed in agreement with the general trends of photosynthesis inhibition. Biotic stress globally downregulates photosynthesis genes (Bilgin et al., 2010). By comparing transcriptomic data from microarray experiments after 22 different forms of biotic damage on eight different plant species, Bilgin et al (Bilgin et al., 2010) reported that transcript levels of photosynthesis light reaction, carbon reduction cycle and pigment synthesis genes decreased regardless of the type of biotic attack. 
Genes coding for the synthesis of jasmonic acid and those involved in the responses to salicylic acid and ethylene were upregulated. The upregulation of JA and SA genes suggest that the downregulation of photosynthesis-related genes was part of a defence response. Analysis of gene clusters revealed that the transcript levels of $84 \%$ of the genes that carry a chloroplast targeting peptide sequence were decreased (Bilgin et al., 2010). The concept of computational network analysis (Liu et al., 2010) appears to be of good relevance as it could assist in identifying not only networks specific to the plant, to the pathogen but also genes that interact between the plant and the pathogen.

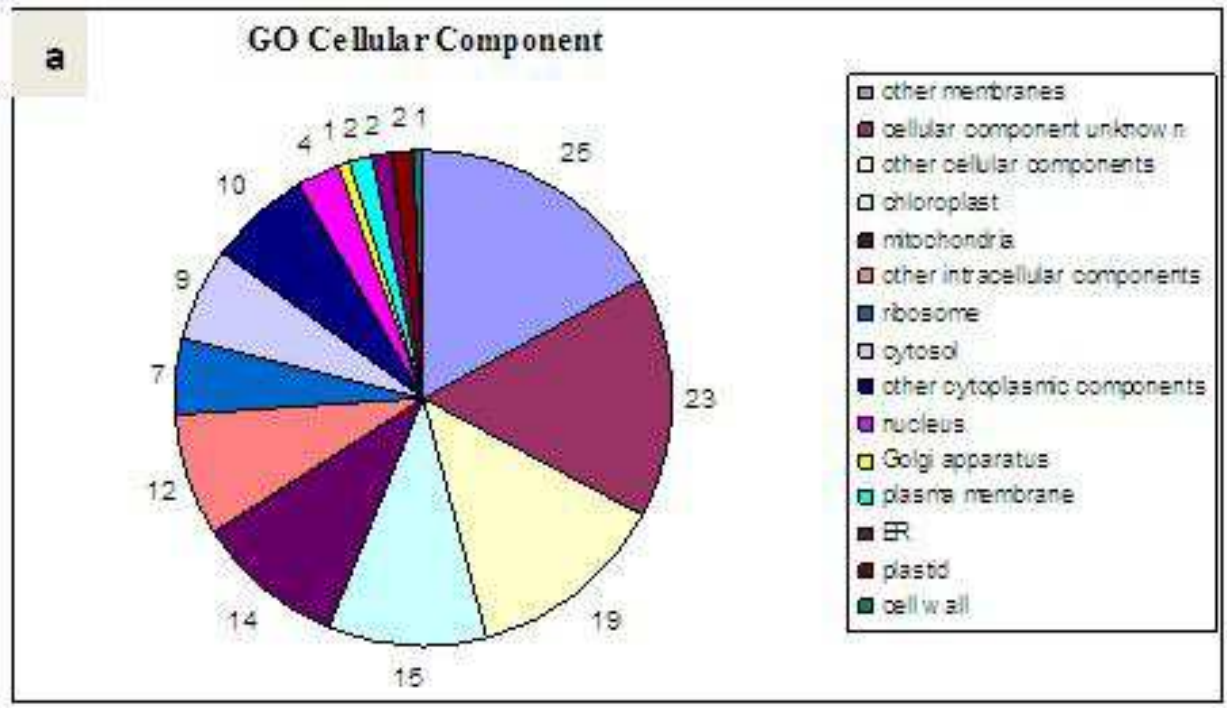

b

\section{GO M olecular Function}

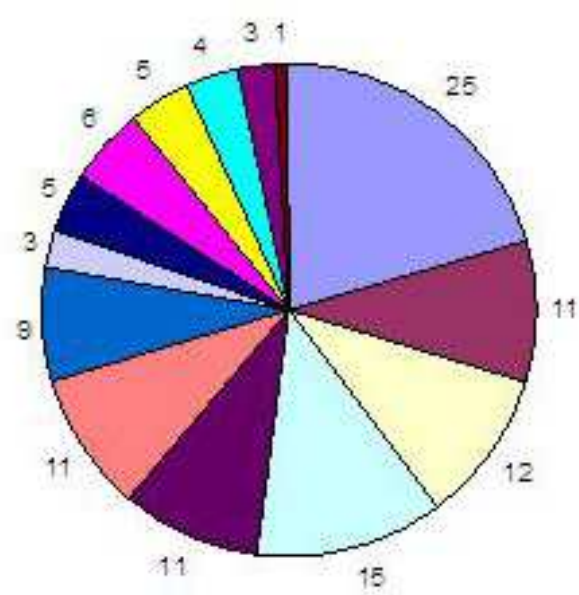

a otherenzyme activty

a borciase activity

口 tansferase activity

a nolacular functon unknow

- other binding

$\square$ rucieobde binding

a structural nolecule activity

a krase activity

- transporter activity

a protein binding

口 DNA or RVA binding

$\square$ other molecular functors

a ruclec acd binding

a tanscripton factor activity 


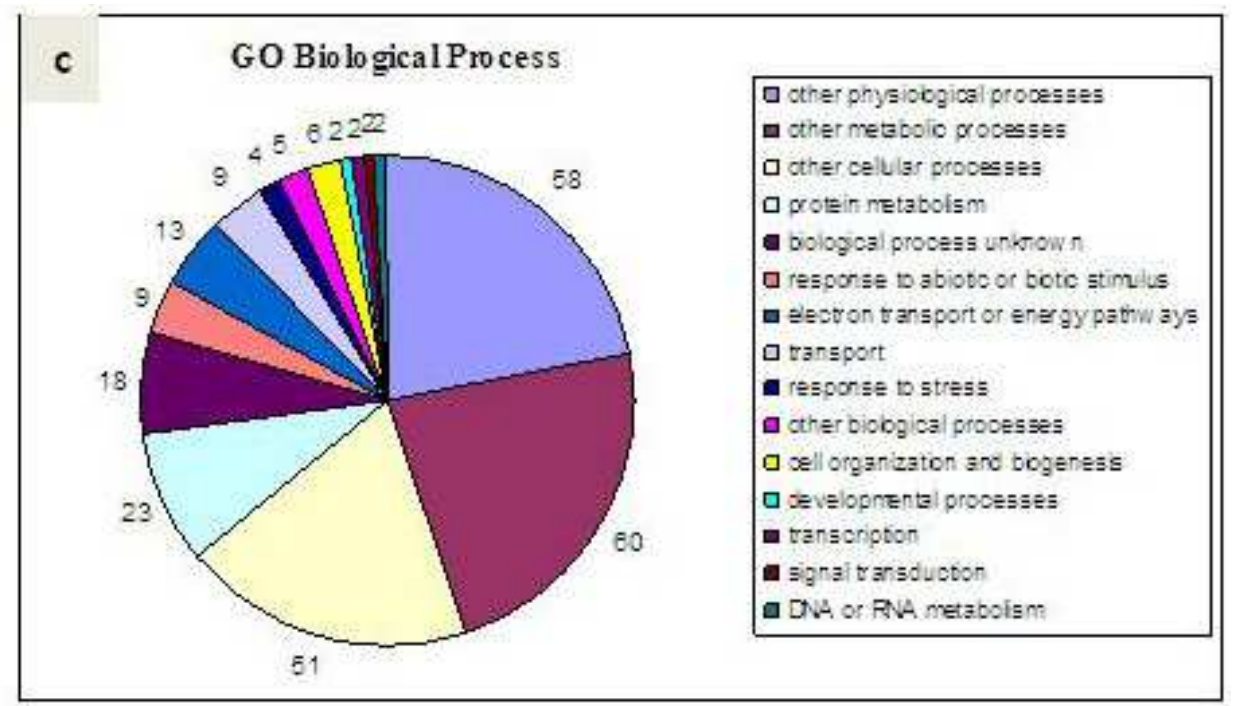

Fig. 3. Gene ontology assignment of differentially expressed genes (Fofana et al., 2007). A BLASTX search of the differentially expressed sequences against the set of predicted Arabidopsis thaliana proteins was used to assign gene ontology. The first hit with an $E$ value less than or equal to $1 \times 10^{-5}$ was used as a functional assignment and the TAIR GO annotation tool was used to bin the genes into the ontology groupings; a) cellular location $b$ ) molecular function and c) biological process.

\subsection{What could be the future strategies?}

Plant productivity depends on the plant's ability to produce higher biomass and seed, which relies on its photosynthetic capacity. However, as mentioned above, this inherent potential is constantly challenged and compromised by phytopathogens. The main question facing plant biologists remains our ability to improve plant productivity under increasing biotic pressure. One of the avenues could consist of emphasizing on gene networks discovery through both computational network discovery strategy (Liu et al., 2010) and gene and proteome analysis in living plants challenged with pathogens. Recently, Zhu et al (Zhu et al., 2010) proposed $C_{4}$ rice as an ideal arena for systems biology research. This group raised the possibility of engineering $C_{4}$ photosynthetic machinery into $C_{3}$ plant such as rice. However, the pivotal role to be played by system biology in identifying key regulatory elements controlling development of $\mathrm{C}_{4}$ features, identifying essential biochemical and anatomical features required to achieve high photosynthetic efficiency, elucidating the genetic mechanisms underlining $\mathrm{C}_{4}$ differentiation and ultimately identifying viable routes to engineer $C_{4}$ rice has been emphasized to decipher the complexity of such engineering (Zhu et al., 2010). A second level complexity comes from the interaction between two organisms as is the case in plant-pathogen interactions. It will be of great interest to put emphasis on the identification of a) more plant gene and protein network clusters and their interactomes, b) more pathogen gene and protein network clusters and their interactomes, c) more plant-pathogen gene and protein network clusters and the interacting genes and proteins linking both organisms, for a better understanding of key target points. This would 
allow the design of strategies to suicide specifically pathogen vital interactome (such as a key component of virulence interactome or life cycle) and to dismantle any genes linking plant-pathogens network clusters through which the invader diverts the photosynthetates for its own. A second avenue could consist of combining system biology approach and agronomic practices that can contribute to increased plant photosynthetic capacity. Recently, Zhang et al (ZhangXie et al., 2008) described a soil symbiotic bacteria that augments photosynthesis in Arabidopsis by decreasing glucose sensing and abscisic acid levels in planta. Would such symbiotic system be applicable in a field system? Would there be any such symbiont that could antagonistically interfere with plant pathogenetic soil born diseases and reduce their impact on plant productivity? Those are some of the questions, we believe, could be the focus for further investigations.

\section{Conclusion}

Photosynthesis is a process that converts solar energy to chemical energy in many different organisms, ranging from plants to bacteria. It provides all the food we eat and all the fossil fuel we use. Photosynthesis of terrestrial higher plants is however constantly challenged by abiotic and biotic stresses. In this review, we described briefly the general process of photosynthesis, its outcome and limiting factors; the complex plant-pathogen interrelationships and their effects on photosynthesis; and the insights the genomics and proteomics era can shed into the elucidation of the many genes and protein clusters and networks that sustain the plant-pathogen interactions in general, and photosynthesis, in particular. Photosynthesis feeds the globe and pathogen threats are increasing. A system biology approach, using both computational gene network discovery and gene and proteome analysis in living plants challenged with pathogens, was proposed as one of the pivotal player in identifying key gene and protein network clusters and their interactomes in both the plant and pathogens towards the design of strategies to suicide specifically pathogen vital interactome and to dismantle any genes linking plant - pathogens network clusters. This approach could be complemented with agronomic practices contributing to increased plant photosynthetic capacity.

\section{Acknowledgments}

The authors warmly thank Dr. Kaushik Ghose (University of Prince Edwards Island) for his kind willingness to proof read this Manuscript. We also wish to acknowledge Dr. Cloutier and her lab (Cereal Research Centre, Agriculture and Agri-Food Canada, Winnipeg, Manitoba), the lab from which Dr. Fofana has performed his work on the leaf-rust pathosystem. This chapter is in recognition and gratitude to Professor Patrick du Jardin (Gembloux Agro-Bio Tech, Universite de Liege, Belgium) from whom I received most of my taste and flavour for molecular plant physiology.

\section{References}

Abrams, M. D., Kubiske, M. E. \& Steiner, K. C. (1990) Drought adaptations and responses in five genotypes of Fraxinus pennsylvanica Marsh.: photosynthesis, water relations and leaf morphology. Tree physiology, 6, 305-15. 
Ackerson, R. C. \& Hebert, R. R. (1981) Osmoregulation in Cotton in Response to Water Stress : I. Alterations in photosynthesis, leaf conductance, translocation, and ultrastructure. Plant physiology, 67, 484-8.

Aguera, E., Ruano, D., Cabello, P. \& de la Haba, P. (2006) Impact of atmospheric CO2 on growth, photosynthesis and nitrogen metabolism in cucumber (Cucumis sativus L.) plants. Journal of plant physiology, 163, 809-17.

Ainsworth, E. A. \& Bush, D. R. (2011) Carbohydrate export from the leaf: a highly regulated process and target to enhance photosynthesis and productivity. Plant physiology, 155, 64-9.

Ainsworth, E. A. \& Rogers, A. (2007) The response of photosynthesis and stomatal conductance to rising [CO2]: mechanisms and environmental interactions. Plant, cell E environment, 30, 258-70.

Albert, K. R., Mikkelsen, T. N. \& Ro-Poulsen, H. (2008) Ambient UV-B radiation decreases photosynthesis in high arctic Vaccinium uliginosum. Physiologia plantarum, 133, 199210.

Allakhverdiev, S. I., Kreslavski, V. D., Klimov, V. V., Los, D. A., Carpentier, R. \& Mohanty, P. (2008) Heat stress: an overview of molecular responses in photosynthesis. Photosynthesis research, 98, 541-50.

Baker, N. R., Long, S. P. \& Ort, D. R. (1988) Photosynthesis and temperature, with particular reference to effects on quantum yield. Symposia of the Society for Experimental Biology, $42,347-75$.

Baldridge, G. D., O'Neill, N. R. \& Samac, D. A. (1998) Alfalfa (Medicago sativa L.) resistance to the root-lesion nematode, Pratylenchus penetrans: defense-response gene mRNA and isoflavonoid phytoalexin levels in roots. Plant molecular biology, 38, 999-1010.

Baldry, C. W., Bucke, C. \& Walker, D. A. (1966) Temperature and photosynthesis. I. Some effects of temperature on carbon dioxide fixation by isolated chloroplasts. Biochimica et biophysica acta, 126, 207-13.

Barhoumi, Z., Djebali, W., Chaibi, W., Abdelly, C. \& Smaoui, A. (2007) Salt impact on photosynthesis and leaf ultrastructure of Aeluropus littoralis. Journal of plant research, 120, 529-37.

Barrow, S. R. \& Cockburn, W. (1982) Effects of light quantity and quality on the decarboxylation of malic Acid in crassulacean Acid metabolism photosynthesis. Plant physiology, 69, 568-71.

Bassham, J. A. (1977) Increasing crop production through more controlled photosynthesis. Science (New York, N.Y.), 197, 630-8.

Batista-Santos, P., Lidon, F. C., Fortunato, A., Leitao, A. E., Lopes, E., Partelli, F., Ribeiro, A. I. \& Ramalho, J. C. (2011) The impact of cold on photosynthesis in genotypes of Coffea spp.-photosystem sensitivity, photoprotective mechanisms and gene expression. Journal of plant physiology, 168, 792-806.

Bauerle, W. L., Bowden, J. D. \& Wang, G. G. (2007) The influence of temperature on withincanopy acclimation and variation in leaf photosynthesis: spatial acclimation to microclimate gradients among climatically divergent Acer rubrum L. genotypes. Journal of experimental botany, 58, 3285-98.

Berger, S., Sinha, A. K. \& Roitsch, T. (2007) Plant physiology meets phytopathology: plant primary metabolism and plant-pathogen interactions. Journal of experimental botany, $58,4019-26$.

Berry, J. A. (1975) Adaptation of photosynthetic processes to stress. Science, 188, 644-650. 
Bertamini, M. \& Nedunchezhian, N. (2004) Photoinhibition and recovery of photosynthesis in leaves of Vitis berlandieri and Vitis rupestris. Journal of plant physiology, 161, 203-10.

Bhatt, R. K., Baig, M. J., Tiwari, H. S. \& Roy, S. (2010) Growth, yield and photosynthesis of Panicum maximum and Stylosanthes hamata under elevated CO2. Journal of environmental biology / Academy of Environmental Biology, India, 31, 549-52.

Biemelt, S. \& Sonnewald, U. (2006) Plant-microbe interactions to probe regulation of plant carbon metabolism. Journal of plant physiology, 163, 307-18.

Bilgin, D. D., Zavala, J. A., Zhu, J., Clough, S. J., Ort, D. R. \& DeLucia, E. H. (2010) Biotic stress globally downregulates photosynthesis genes. Plant, cell $\mathcal{E}$ environment, 33, 1597-613.

Bilska, A. \& Sowinski, P. (2010) Closure of plasmodesmata in maize (Zea mays) at low temperature: a new mechanism for inhibition of photosynthesis. Annals of botany, $106,675-86$.

Bischof, K., Hanelt, D. \& Wiencke, C. (2000) Effects of ultraviolet radiation on photosynthesis and related enzyme reactions of marine macroalgae. Planta, 211, 555-62.

Bonfig, K. B., Schreiber, U., Gabler, A., Roitsch, T. \& Berger, S. (2006) Infection with virulent and avirulent $P$. syringae strains differentially affects photosynthesis and sink metabolism in Arabidopsis leaves. Planta, 225, 1-12.

Chou, H. M., Bundock, N., Rolfe, S. A. \& Scholes, J. D. (2000) Infection of Arabidopsis thaliana leaves with Albugo candida (white blister rust) causes a reprogramming of host metabolism. Mol Plant Pathol 1, 99-113.

Daayf, F., Schmitt, A. \& Belanger, R. R. (1997) Evidence of Phytoalexins in Cucumber Leaves Infected with Powdery Mildew following Treatment with Leaf Extracts of Reynoutria sachalinensis. Plant physiology, 113, 719-727.

Dixon, R. A., Harrison, M. J. \& Paiva, L. N. (1995) The isoflavonoid phytoalexin pathway: From enzymes to genes to transcription factors. Physiol Plant, 93, 385-392.

Dodds, P. N. \& Rathjen, J. P. (2010) Plant immunity: towards an integrated view of plantpathogen interactions. Nature reviews. Genetics, 11, 539-48.

Duggan, D. J., Bittner, M., Chen, Y., Meltzer, P. \& Trent, J. M. (1999) Expression profiling using cDNA microarrays. Nature genetics, 21, 10-4.

Eichmann, R., Biemelt, S., Schafer, P., Scholz, U., Jansen, C., Felk, A., Schafer, W., Langen, G., Sonnewald, U., Kogel, K. H. \& Huckelhoven, R. (2006) Macroarray expression analysis of barley susceptibility and nonhost resistance to Blumeria graminis. Journal of plant physiology, 163, 657-70.

El-Bebany, A. F., Rampitsch, C. \& Daayf, F. (2010) Proteomic analysis of the phytopathogenic soilborne fungus Verticillium dahliae reveals differential protein expression in isolates that differ in aggressiveness. Proteomics, 10, 289-303.

Elmore, J. M. \& Coaker, G. (2011a) Biochemical purification of native immune protein complexes. Methods in molecular biology (Clifton, N.J.), 712, 31-44.

Elmore, J. M. \& Coaker, G. (2011b) The Role of the Plasma Membrane H+-ATPase in PlantMicrobe Interactions. Molecular plant, 4, 416-27.

Elmore, J. M., Lin, Z. J. \& Coaker, G. (2011) Plant NB-LRR signaling: upstreams and downstreams. Current opinion in plant biology.

Erickson, S. J. \& Hawkins, C. E. (1980) Effects of halogenated organic compounds on photosynthesis in estuarine phytoplankton. Bulletin of environmental contamination and toxicology, 24, 910-5. 
Essmann, J., Bones, P., Weis, E. \& Scharte, J. (2008) Leaf carbohydrate metabolism during defense: Intracellular sucrose-cleaving enzymes do not compensate repression of cell wall invertase. Plant signaling $\mathcal{E}$ behavior, 3, 885-7.

Eulgem, T. (2005) Regulation of the Arabidopsis defense transcriptome. Trends in plant science, 10, 71-8.

Faris, J. D., Zhang, Z., Lu, H., Lu, S., Reddy, L., Cloutier, S., Fellers, J. P., Meinhardt, S. W., Rasmussen, J. B., Xu, S. S., Oliver, R. P., Simons, K. J. \& Friesen, T. L. (2010) A unique wheat disease resistance-like gene governs effector-triggered susceptibility to necrotrophic pathogens. Proceedings of the National Academy of Sciences of the United States of America, 107, 13544-9.

Fawe, A., Abou-Zaid, M., Menzie, J. G. \& Belanger, R. R. (1998) Silicon-mediated accumulation of flavonoid phytoalexins in cucumber. Phytopathology, 88, 396-401.

Fofana, B., Banks, T. W., McCallum, B., Strelkov, S. E. \& Cloutier, S. (2007) Temporal gene expression profiling of the wheat leaf rust pathosystem using cDNA microarray reveals differences in compatible and incompatible defence pathways. International journal of plant genomics, 2007, 17542.

Fofana, B., Benhamou, N., McNally, D., Labbe, C., Seguin, A. \& Belanger, R. (2005) Suppression of Induced Resistance in Cucumber Through Disruption of the Flavonoid Pathway. Phytopathology, 95.

Fofana, B., McNally, D., Labbe, C., Boulanger, R., Benhamou, N., Seguin, A. \& Belanger, R. (2002) Milsana-Induced Resistance in Powdery Mildew-Infected Cucumber Plants Correlates with the Induction of Chalcone Synthase and Chalcone Isomerase. Physiol Plant Mol Pathol, 61, 121-132.

Fu, J., Liu, H., Li, Y., Yu, H., Li, X., Xiao, J. \& Wang, S. (2011) Manipulating broad-spectrum disease resistance by suppressing pathogen-induced auxin accumulation in rice. Plant physiology, 155, 589-602.

Garavaglia, B. S., Thomas, L., Gottig, N., Zimaro, T., Garofalo, C. G., Gehring, C. \& Ottado, J. (2010) Shedding light on the role of photosynthesis in pathogen colonization and host defense. Communicative \& integrative biology, 3, 382-4.

Garg, H., Li, H., Sivasithamparam, K., Kuo, J. \& Barbetti, M. J. (2010) The infection processes of Sclerotinia sclerotiorum in cotyledon tissue of a resistant and a susceptible genotype of Brassica napus. Annals of botany, 106, 897-908.

Gehring, C. A. \& Irving, H. R. (2003) Natriuretic peptides--a class of heterologous molecules in plants. The international journal of biochemistry \& cell biology, 35, 1318-22.

Gest, H. (1993) Photosynthetic and quasi-photosynthetic bacteria. FEMS Microbiol Lett, 112, $1-6$.

Gest, H. (2002) History of the word photosynthesis and evolution of its definition. Photosynthesis research, 73, 7-10.

Gonzalez-Teuber, M., Pozo, M. J., Muck, A., Svatos, A., Adame-Alvarez, R. M. \& Heil, M. (2010) Glucanases and chitinases as causal agents in the protection of Acacia extrafloral nectar from infestation by phytopathogens. Plant physiology, 152, 170515.

Guldener, U., Mannhaupt, G., Munsterkotter, M., Haase, D., Oesterheld, M., Stumpflen, V., Mewes, H. W. \& Adam, G. (2006) FGDB: a comprehensive fungal genome resource on the plant pathogen Fusarium graminearum. Nucleic acids research, 34, D456-8.

Guldener, U., Seong, K. Y., Boddu, J., Cho, S., Trail, F., Xu, J. R., Adam, G., Mewes, H. W., Muehlbauer, G. J. \& Kistler, H. C. (2006) Development of a Fusarium graminearum 
Affymetrix GeneChip for profiling fungal gene expression in vitro and in planta. Fungal genetics and biology: FG \& B, 43, 316-25.

Halitschke, R., Hamilton, J. G. \& Kessler, A. (2011) Herbivore-specific elicitation of photosynthesis by mirid bug salivary secretions in the wild tobacco Nicotiana attenuata. The New phytologist.

Hammerschmidt, R. \& Kuc, J. (1982) Lignification as a mechanism for induced systemic resistance in cucumber Physiol Plant Pathol 20 61-71.

Hammerschmidt, R. \& Yang-Cashman, P. (1995) Induced Resistance in Cucurbits. Induced Resistance to disease in plants (ed R. H. a. J. Kuć), pp. 63-85. Kluwer Academic Publishers, The Netherlands.

Horst, R. J., Engelsdorf, T., Sonnewald, U. \& Voll, L. M. (2008) Infection of maize leaves with Ustilago maydis prevents establishment of C4 photosynthesis. Journal of plant physiology, 165, 19-28.

Hu, G. \& Rijkenberg, F. H. (1998a) Subcellular localization of beta-1,3-glucanase in Puccinia recondita f.sp. tritici-infected wheat leaves. Planta, 204, 324-34.

Hu, G. \& Rijkenberg, F. H. J. (1998b) Scanning electron microscopy of early infection structure formation by Puccinia recondita f. $s p$. tritici on and in susceptible and resistant wheat lines. Mycological Research, 102, 391-399.

Ibanez, A. J., Scharte, J., Bones, P., Pirkl, A., Meldau, S., Baldwin, I. T., Hillenkamp, F., Weis, E. \& Dreisewerd, K. (2010) Rapid metabolic profiling of Nicotiana tabacum defence responses against Phytophthora nicotianae using direct infrared laser desorption ionization mass spectrometry and principal component analysis. Plant methods, 6, 14.

Ishihara, A., Hashimoto, Y., Miyagawa, H. \& Wakasa, K. (2008) Induction of serotonin accumulation by feeding of rice striped stem borer in rice leaves. Plant signaling $\mathcal{E}$ behavior, 3, 714-6.

Ishihara, A., Hashimoto, Y., Tanaka, C., Dubouzet, J. G., Nakao, T., Matsuda, F., Nishioka, T., Miyagawa, H. \& Wakasa, K. (2008) The tryptophan pathway is involved in the defense responses of rice against pathogenic infection via serotonin production. The Plant journal : for cell and molecular biology, 54, 481-95.

Ishihara, A., Nakao, T., Mashimo, Y., Murai, M., Ichimaru, N., Tanaka, C., Nakajima, H., Wakasa, K. \& Miyagawa, H. (2011) Probing the role of tryptophan-derived secondary metabolism in defense responses against Bipolaris oryzae infection in rice leaves by a suicide substrate of tryptophan decarboxylase. Phytochemistry, 72, 7-13.

Jagadeeswaran, G., Raina, S., Acharya, B. R., Maqbool, S. B., Mosher, S. L., Appel, H. M., Schultz, J. C., Klessig, D. F. \& Raina, R. (2007) Arabidopsis GH3-LIKE DEFENSE GENE 1 is required for accumulation of salicylic acid, activation of defense responses and resistance to Pseudomonas syringae. The Plant journal : for cell and molecular biology, 51, 234-46.

Kim, Y. M., Bouras, N., Kav, N. N. \& Strelkov, S. E. (2010) Inhibition of photosynthesis and modification of the wheat leaf proteome by Ptr ToxB: a host-specific toxin from the fungal pathogen Pyrenophora tritici-repentis. Proteomics, 10, 2911-26.

King, E. G. \& Caylor, K. K. (2010) Herbivores and mutualistic ants interact to modify tree photosynthesis. The New phytologist, 187, 17-21.

Kocal, N., Sonnewald, U. \& Sonnewald, S. (2008) Cell wall-bound invertase limits sucrose export and is involved in symptom development and inhibition of photosynthesis 
during compatible interaction between tomato and Xanthomonas campestris pv vesicatoria. Plant physiology, 148, 1523-36.

Korves, T. M. \& Bergelson, J. (2003) A developmental response to pathogen infection in Arabidopsis. Plant physiology, 133, 339-47.

Kumar, A., Li, C. \& Portis, A. R., Jr. (2009) Arabidopsis thaliana expressing a thermostable chimeric Rubisco activase exhibits enhanced growth and higher rates of photosynthesis at moderately high temperatures. Photosynthesis research, 100, 14353.

Kurek, I., Chang, T. K., Bertain, S. M., Madrigal, A., Liu, L., Lassner, M. W. \& Zhu, G. (2007) Enhanced Thermostability of Arabidopsis Rubisco activase improves photosynthesis and growth rates under moderate heat stress. The Plant cell, 19, 3230-41.

Lee, S., Kim, S. Y., Chung, E., Joung, Y. H., Pai, H. S., Hur, C. G. \& Choi, D. (2004) EST and microarray analyses of pathogen-responsive genes in hot pepper (Capsicum annuum L.) non-host resistance against soybean pustule pathogen (Xanthomonas axonopodis pv. glycines). Functional E integrative genomics, 4, 196-205.

Liu, J., Elmore, J. M., Lin, Z. J. \& Coaker, G. (2011) A receptor-like cytoplasmic kinase phosphorylates the host target RIN4, leading to the activation of a plant innate immune receptor. Cell host $\mathcal{E}$ microbe, 9, 137-46.

Liu, X., Tang, W. H., Zhao, X. M. \& Chen, L. (2010) A network approach to predict pathogenic genes for Fusarium graminearum. PloS one, 5 .

McNally, D. J., Wurms, K. V., Labbe, C. \& Belanger, R. R. (2003b) Synthesis of C-glycosyl flavonoid phytoalexins as a site-specific response to fungal penetration in cucumber. Physiol Plant Mol Pathol, 63, 293-303.

McNally, D. J., Wurms, K. V., Labbe, C., Quideau, S. \& Belanger, R. R. (2003) Complex Cglycosyl flavonoid phytoalexins from Cucumis sativus. Journal of natural products, 66, 1280-3.

Murchie, E. H. \& Niyogi, K. K. (2011) Manipulation of photoprotection to improve plant photosynthesis. Plant physiology, 155, 86-92.

Nabity, P. D., Zavala, J. A. \& DeLucia, E. H. (2009) Indirect suppression of photosynthesis on individual leaves by arthropod herbivory. Annals of botany, 103, 655-63.

Navarro, L., Dunoyer, P., Jay, F., Arnold, B., Dharmasiri, N., Estelle, M., Voinnet, O. \& Jones, J. D. (2006) A plant miRNA contributes to antibacterial resistance by repressing auxin signaling. Science (New York, N.Y.), 312, 436-9.

Nembaware, V., Seoighe, C., Sayed, M. \& Gehring, C. (2004) A plant natriuretic peptide-like gene in the bacterial pathogen Xanthomonas axonopodis may induce hyper-hydration in the plant host: a hypothesis of molecular mimicry. BMC evolutionary biology, 4, 10.

Nunes-Nesi, A., Sulpice, R., Gibon, Y. \& Fernie, A. R. (2008) The enigmatic contribution of mitochondrial function in photosynthesis. Journal of experimental botany, 59, 1675-84.

OED (1989) Oxford English Dictionary. The Oxford English Dictionary (ed E. W. John Simpson). Clarendon Press, Oxford.

Paul, M. J. \& Foyer, C. H. (2001) Sink regulation of photosynthesis. Journal of experimental botany, 52, 1383-400.

Paul, M. J. \& Pellny, T. K. (2003) Carbon metabolite feedback regulation of leaf photosynthesis and development. Journal of experimental botany, 54, 539-47.

Petit, A. N., Vaillant, N., Boulay, M., Clement, C. \& Fontaine, F. (2006) Alteration of photosynthesis in grapevines affected by esca. Phytopathology, 96, 1060-6. 
Rekah, Y., Shtienberg, D. \& Katan, J. (1999) Spatial distribution and temporal development of Fusarium crown and root rot of tomato and pathogen dissemination in field soil Phytopathology 89, 831-839.

Rhodes, M. J. (1994) Physiological roles for secondary metabolites in plants: some progress, many outstanding problems. Plant molecular biology, 24, 1-20.

Ripley, B. S., Abraham, T. I. \& Osborne, C. P. (2008) Consequences of C4 photosynthesis for the partitioning of growth: a test using C3 and C4 subspecies of Alloteropsis semialata under nitrogen-limitation. Journal of experimental botany, 59, 1705-14.

Ripley, B. S., Gilbert, M. E., Ibrahim, D. G. \& Osborne, C. P. (2007) Drought constraints on C4 photosynthesis: stomatal and metabolic limitations in C3 and C4 subspecies of Alloteropsis semialata. Journal of experimental botany, 58, 1351-63.

Roberntz, P. \& Stockfors, J. (1998) Effects of elevated CO(2) concentration and nutrition on net photosynthesis, stomatal conductance and needle respiration of field-grown Norway spruce trees. Tree physiology, 18, 233-241.

Romeis, T. (2001) Protein kinases in the plant defence response. Current opinion in plant biology, 4, 407-14.

Romeis, T., Ludwig, A. A., Martin, R. \& Jones, J. D. (2001) Calcium-dependent protein kinases play an essential role in a plant defence response. The EMBO journal, 20, 5556-67.

Scharte, J., Schon, H., Tjaden, Z., Weis, E. \& von Schaewen, A. (2009) Isoenzyme replacement of glucose-6-phosphate dehydrogenase in the cytosol improves stress tolerance in plants. Proceedings of the National Academy of Sciences of the United States of America, 106, 8061-6.

Schenk, P. M., Kazan, K., Wilson, I., Anderson, J. P., Richmond, T., Somerville, S. C. \& Manners, J. M. (2000) Coordinated plant defense responses in Arabidopsis revealed by microarray analysis. Proceedings of the National Academy of Sciences of the United States of America, 97, 11655-60.

Seo, Y. S., Cho, J. I., Lee, S. K., Ryu, H. S., Han, M., Hahn, T. R., Sonnewald, U. \& Jeon, J. S. (2007) Current insights into the primary carbon flux that occurs in plants undergoing a defense response Plant Stress 1, 42-49.

Song, X., Rampitsch, C., Soltani, B., Mauthe, W., Linning, R., Banks, T., McCallum, B. \& Bakkeren, G. (2011) Proteome analysis of wheat leaf rust fungus, Puccinia triticina, infection structures enriched for haustoria. Proteomics, 11, 944-63.

Strelkov, S. E., Lamari, L. \& Ballance, G. M. (1998) Induced chlorophyll degradation by a chlorosis toxin from Pyrenophora tritici-repentis Can. J. Plant Pathol., 20, 428-435.

Taiz, L. \& Zeiger, E. (2010) Plant Physiology. Sinauer Associates Inc, Sunderland, Massachussetts, USA.

Tang, J., Zielinski, R., Aldea, M. \& DeLucia, E. (2009) Spatial association of photosynthesis and chemical defense in Arabidopsis thaliana following herbivory by Trichoplusia ni. Physiologia plantarum, 137, 115-24.

Tariq, V. N. \& Jeffries, P. (1986) Ultrastructure of penetration of Phaseolus spp. by Sclerotinia sclerotiorum. Canadian Journal of Botany, 64, 2909-2015.

Tariq, V. N. \& Jeffries, P. ( 1984) Appressorium formation by Sclerotinia sclerotiorum: scanning electron microscopy. . Transactions of British Mycological Society 82.

Trotta, A., Wrzaczek, M., Scharte, J., Tikkanen, M., Konert, G., Rahikainen, M., Holmstrom, M., Hiltunen, H. M., Rips, S., Sipari, N., Mulo, P., Weis, E., von Schaewen, A., Aro, E. M. \& Kangasjarvi, S. (2011) Regulatory subunit $B^{\prime}\{$ gamma $\}$ of protein 
phosphatase 2A prevents unnecessary defense reactions under low light in Arabidopsis thaliana. Plant physiology, 156, 1464-1480.

Vidaver, A. K. \& Lambrecht, P. A. (2004) Bacteria as plant pathogens. The plant health Instructor, DOI: 10.1094/PHI-I-2004-0809-01.

Voegele, R. T., Wirsel, S., Moll, U., Lechner, M. \& Mendgen, K. (2006) Cloning and characterization of a novel invertase from the obligate biotroph Uromyces fabae and analysis of expression patterns of host and pathogen invertases in the course of infection. Mol Plant Microbe Interact 19, 625-634.

Ward, E. R., Uknes, S. J., Williams, S. C., Dincher, S. S., Wiederhold, D. L., Alexander, D. C., Ahl-Goy, P., Metraux, J. P. \& Ryals, J. A. (1991) Coordinate Gene Activity in Response to Agents That Induce Systemic Acquired Resistance. The Plant cell, 3, 1085-1094.

Wen, Y., Wang, W., Feng, J., Luo, M. C., Tsuda, K., Katagiri, F., Bauchan, G. \& Xiao, S. (2011) Identification and utilization of a sow thistle powdery mildew as a poorly adapted pathogen to dissect post-invasion non-host resistance mechanisms in Arabidopsis. Journal of experimental botany, 62, 2117-29.

Wurms, K., Labbe, C., Benhamou, N. \& Belanger, R. (1999) Effects of Milsana and Benzothiadiazole on the Ultrastructure of Powdery Mildew Haustoria on Cucumber. Phytopathology, 89, 728-736.

Zhang, C. \& Turgeon, R. (2009) Downregulating the sucrose transporter VpSUT1 in Verbascum phoeniceum does not inhibit phloem loading. Proceedings of the National Academy of Sciences of the United States of America, 106, 18849-54.

Zhang, H., Xie, X., Kim, M. S., Kornyeyev, D. A., Holaday, S. \& Pare, P. W. (2008) Soil bacteria augment Arabidopsis photosynthesis by decreasing glucose sensing and abscisic acid levels in planta. The Plant journal : for cell and molecular biology, 56, 26473.

Zhang, X., Wollenweber, B., Jiang, D., Liu, F. \& Zhao, J. (2008) Water deficits and heat shock effects on photosynthesis of a transgenic Arabidopsis thaliana constitutively expressing ABP9, a bZIP transcription factor. Journal of experimental botany, 59, 83948.

Zhang, Z., Friesen, T. L., Xu, S. S., Shi, G., Liu, Z., Rasmussen, J. B. \& Faris, J. D. (2011) Two putatively homoeologous wheat genes mediate recognition of SnTox3 to confer effector-triggered susceptibility to Stagonospora nodorum. The Plant journal : for cell and molecular biology, 65, 27-38.

Zhao, X. M., Zhang, X. W., Tang, W. H. \& Chen, L. (2009) FPPI: Fusarium graminearum protein-protein interaction database. Journal of proteome research, 8, 4714-21.

Zhu, X. G., Shan, L., Wang, Y. \& Quick, W. P. (2010) C4 rice - an ideal arena for systems biology research. Journal of integrative plant biology, 52, 762-70.

Zou, J., Rodriguez-Zas, S., Aldea, M., Li, M., Zhu, J., Gonzalez, D. O., Vodkin, L. O., DeLucia, E. \& Clough, S. J. (2005) Expression profiling soybean response to Pseudomonas syringae reveals new defense-related genes and rapid HR-specific downregulation of photosynthesis. Molecular plant-microbe interactions : MPMI, 18, 1161-74. 


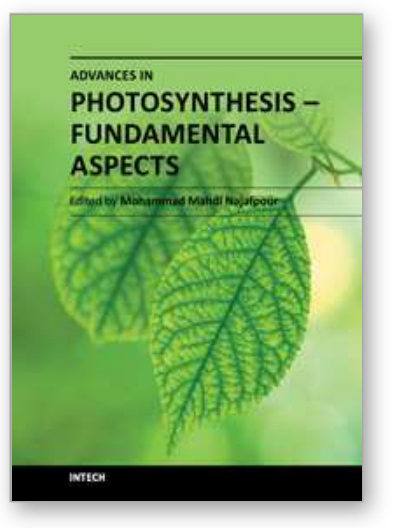

\section{Advances in Photosynthesis - Fundamental Aspects \\ Edited by Dr Mohammad Najafpour}

ISBN 978-953-307-928-8

Hard cover, 588 pages

Publisher InTech

Published online 15, February, 2012

Published in print edition February, 2012

Photosynthesis is one of the most important reactions on Earth. It is a scientific field that is the topic of many research groups. This book is aimed at providing the fundamental aspects of photosynthesis, and the results collected from different research groups. There are three sections in this book: light and photosynthesis, the path of carbon in photosynthesis, and special topics in photosynthesis. In each section important topics in the subject are discussed and (or) reviewed by experts in each book chapter.

\section{How to reference}

In order to correctly reference this scholarly work, feel free to copy and paste the following:

Kumarakurubaran Selvaraj and Bourlaye Fofana (2012). An Overview of Plant Photosynthesis Modulation by Pathogen Attacks, Advances in Photosynthesis - Fundamental Aspects, Dr Mohammad Najafpour (Ed.), ISBN: 978-953-307-928-8, InTech, Available from: http://www.intechopen.com/books/advances-in-photosynthesisfundamental-aspects/an-overview-of-plant-photosynthesis-modulation-by-pathogen-attacks

\section{INTECH}

open science | open minds

\section{InTech Europe}

University Campus STeP Ri

Slavka Krautzeka 83/A

51000 Rijeka, Croatia

Phone: +385 (51) 770447

Fax: +385 (51) 686166

www.intechopen.com

\section{InTech China}

Unit 405, Office Block, Hotel Equatorial Shanghai

No.65, Yan An Road (West), Shanghai, 200040, China

中国上海市延安西路65号上海国际贵都大饭店办公楼 405 单元

Phone: +86-21-62489820

Fax: $+86-21-62489821$ 
(C) 2012 The Author(s). Licensee IntechOpen. This is an open access article distributed under the terms of the Creative Commons Attribution 3.0 License, which permits unrestricted use, distribution, and reproduction in any medium, provided the original work is properly cited. 